DOI https://doi.org/10.36059/978-966-397-235-0-21

\author{
Стрельцов $\epsilon$. Л., \\ доктор юридичних наук, доктор теології, професор, \\ заслужений діяч науки і техніки України, \\ член-кореспондент Національної академії правових наук України, \\ завідувач кафедри кримінального права \\ Національного університету «Одеська юридична академія», \\ м. Oдеса \\ Сотула О. C., \\ доктор юридичних наук, професор, \\ професор кафедри кримінального права \\ Національного університету «Одеська юридична академія», \\ M. Odeca \\ Стрельцов Л. $\epsilon$., \\ кандидат юридичних наук, \\ директор \\ одеської філії \\ Інституту прикладних гуманітарних досліджень, \\ м. Oдеса

\section{ЖИТТЯ ЛЮДИНИ ТА ЇЇ ПРАВО НА ЖИТТЯ ЯК ОБ'ЄКТ КРИМІНАЛЬНО-ПРАВОВОЇ ОХОРОНИ: ПОРІВНЯЛЬНО-ПРАВОВИЙ ДИСКУРС}

Анотація. Життя людини є загальним предметом правового регулювання, якій має багато напрямів своє реалізації. Одним з основним напрямів, якій потребує такого регулювання, виступає життя людини як об'єкт правової охорони, зокрема й кримінально-правовими засобами. Водночас життя людини має певну правову форму, виступає суб'єктивним правочином із формально-атрибутивними ознаками, які закріплені $в$ Конституції Украӥни, важливих міжнародно-правових та вітчизняних актах. Право на життя $\epsilon$ невід'ємним правом кожної людини, що охороняється законом та накладає на державу відповідні зобов'язання зробити все для того, щоб людське життя виявилася поза небезпекою. 
Права людини в Україні та у зарубіжних країнах: традиції та новації

Життя людини має просторово-часову характеристику, яка має свій початок і своє закінчення, що повинно мати своє відображення у відповідних правових приписах, зокрема й у нормах. Водночас аналіз загальноприйнятих у кримінальноправовій доктрині положень про те, що встановлення цього, особливо коли це пов'язано з початком життя, має певну дискусійність, що потребує продовження кримінально-правових досліджень у цьому напрямі. Із цією метою формулюються пропозиції щодо вдосконалення положень Кримінального кодексу України стосовно кримінально-правової охорони життя людини.

\section{Вступ}

Життя людини як об'єкт юридичної охорони життя вперше закріплене в чинній Конституції України. Жодна з попередніх конституцій української держави, а також минуле поточне галузеве законодавство положень про право на життя не містили. Законодавство охороняло окремі складові частини суспільного життя, які стосувалися різних сфер такої дійсності, як-от недоторканість особи, таємниця її листування, лікарська таємниця тощо [1]. Але в сучасних умовах набуває актуальності реалізація суб'єктивного права людини на життя.

Визнання державою права на життя означає, що життя людини $є$ найвищою цінністю, тому що всі інші права та свободи та їх реалізація залежать від цього права. Право на життя $\epsilon$ необхідною умовою інших прав і свобод. У цьому розумінні право на життя має абсолютний характер.

Саме тому положення про право на життя проголошене всіма найважливішими міжнародно-правовими документами із прав людини. Так, у ст. 3 Загальної декларації прав людини констатується, що «кожна людина має право на життя, на свободу та на особисту недоторканність» [2]. У Міжнародного пакту про громадянські i політичні права зазначено: «Право на життя $\epsilon$ невід'ємним правом кожної людини. Це право охороняється законом. Ніхто не може бути довільно позбавлений життя» [3]. Зв'язок права на життя та заборони довільного його позбавлення підкреслюється й у Європейській конвенції про захист прав людини та основних свобод від 4 листопада 1950 р. [4]. Регіональні конвенції також дотримуються такої традиції [5]. 
Права людини в Україні та у зарубіжних країнах: традиції та новації

Фундаментальний характер права на життя широко визнається як міжнародними судами із прав людини, так i багатьма теоретиками в цій області [6, с. 27]. Навіть більше, визначення цього права як «невід'ємного» (ст. 6 Міжнародної конвенції про громадянські і політичні права) показує також, що воно є частиною міжнародного звичаєвого права [3].

\section{1. Конституційні засади охорони життя людини}

Текстуальне закріплення в європейських конституціях права на життя будується практично за однаковою схемою. Або коротка констатація даного права (ст. 28 Конституції Республіки Болгарія [7]; ст. 2 Конституції Федеративної Республіки Німеччина [8]; ст. 21 Конституційного закону Республіки Албанія [9]), або ще фіксуються й гарантії недопущення довільної смертної кари або цілковитої заборони на застосування даного виду покарання. Наприклад, Конституція Португалії проголошує: «1. Людське життя недоторканне. 2. Застосування смертної кари не допускається» (ст. 24) [10]. Таким же прикладом є ст. 21 Конституції Республіки Хорватія: «Кожна людина має право на життя. У Республіці Хорватія немає смертної кари» [11]. Аналогічне формулювання міститься в Конституції Республіки Словенія: «Людське життя недоторканне. У Словенії немає смертної кари» (ст. 17) [12].

Конституція Словацької Республіки (ст. 15) і Хартія основних прав і свобод Чеської Республіки (ст. 6) додатково виділяють, що людське життя гідне охорони ще до народження $[13 ; 14]$.

Нерідко конституційне закріплення права на життя відбувається в комплексі з іншими правами в рамках однієї статті. Прикладом може служити ст. 15 Конституції Іспанії: «Усі мають право на життя, фізичну та моральну недоторканність, нікого в жодному разі не можна піддавати катуванням або нелюдському чи такому, що принижує гідність, поводженню. Скасовується смертна кара, за винятком випадків, передбачених військовими кримінальними законами під час війни» [15].

Однак треба сказати, що саме право на життя вперше знайшло своє нормативне закріплення лише наприкінці XVIII ст. в Декларації незалежності США від 4 липня 1776 р., у якій першою серед «самоочевидних істин» проголошувалася та, що «усі люди створені рівними, усі вони наділені певними невідчужуваними правами, до яких належать Життя, Свобода і прагнення Щастя» [16]. 
3 ухваленням Декларації у світі стали затверджуватися правила про те, що право на життя, яке являє собою абсолютну цінність світової цивілізації, повинно перебувати під максимальним правовим захистом. Право зобов'язано охороняти життя будь-якої людини незалежно від її статі, віку, расової або національної приналежності, незалежно від місця та ролі в суспільстві, незалежно від стану здоров'я. Життя людини повинно охоронятися як абсолютне благо, на яке ніхто не має права посягати.

Однак точні нормативні межі права на життя дещо розмиті. Ще в середині XIX ст. професорами П.I. Новгородцевим i Й.О. Покровським основним компонентом права на життя виділялося право на існування (малися на увазі необхідні та достатні умови для підтримки фізіологічної діяльності організму: їжа, медикаменти тощо) [17]. Професор П.І. Новгородцев зазначав, що «мова йде про те, щоб забезпечити для кожного можливість існування та звільнити від гніту таких умов життя, які вбивають фізично й морально» [17, с. 4]. Право, згідно з його науковою концепцією, повинно взяти на себе визначення тих умовних меж, що окреслюють той рівень життя, який уважається нормою. За його межами починається неприпустима крайність, яка, зокрема, може виражатися в реальній загрозі голодної смерті конкретної особи [17, с. 5].

Професор Й.О. Покровський розвинув цю думку та підкреслив: «Якщо держава визнає себе зобов'язаною рятувати людей від голодної смерті - виходить, кожна окрема людина має право вимагати цього від держави, i, таким чином, шукане право на існування вже є» $[17$, с. 6]. Така позиція знаходить своїх прихильників і сьогодні $[18$, с. $64 ; 19$, с. 4$]$.

На нашу думку, досить необачно ставити знак рівності між правом на життя та правом на існування. Оскільки право на існування радше становить зміст іншого самостійного соціального права індивіда - права на достатній рівень життя.

Деякі вчені стверджують, що право на життя кваліфікується в міжнародному праві як імперативна норма, і вираз «невід'ємне право на життя» не має розумітися в обмеженому значенні. Так, американський медіадослідник Хал Борленд розглядав, як право на життя регулюється американською Конституцією, і зазначав: «Право на життя, на людське життя, $\epsilon$ щось більше, ніж право на просте існування. Усі ми маємо право на існування, але воно 
Права людини в Україні та у зарубіжних країнах: традиції та новації

надається нам поряд 3 обов'язком прожити корисне життя життя, присвячене якійсь меті. Без цього життя не має осмисленого значення» [21, с. 22]. Наведене висловлення припускає, що «життя повинно розглядатися правом не тільки як форма біологічного існування, але і як спосіб самореалізації конкретної особистості» [22, с. 7].

Як зазначають дослідники життя людини як об'єкта правового регулювання, структура певного права визначається структурою правоохоронюваного об'єкта. Життя людини має трискладову структуру:

1) життя фізичне - як функціонування організму людини;

2) життя соціальне - як сукупність суспільних відносин, у які людина вступає як представник різних соціальних об'єднань (родина, професійний колектив, держава тощо);

3) життя внутрішнє, внутрішній світ людини, - як результат діяльності свідомості та несвідомого в людині [19, с. 7; 20, с. 26].

У зв'язку із цим життя $\epsilon$ не безпосереднім предметом правового регулювання, а лише предметом правових відносин, змістом яких $€$ суб'єктивні права і юридичні обов'язки, які забезпечують його схоронність і юридично значущі якості $[23$, с. 4].

У зв'язку з нормативним закріпленням у ст. 27 Конституції України у права на життя з'явилася можливість його самостійного розгляду [24]. Право на життя - це самостійне право, що має властиву тільки йому внутрішню складну структуру та зміст, адже воно не означає, що держава тим самим санкціонує, дозволяє життя власних громадян. Життя виникає поза державними веліннями, і біологічне народження дитини найменше потребує наявності державних інститутів. Як відзначав професор М.М. Алексєєв, «юридична норма не має здатності створювати живі істоти» [25, с. 79]. Коли держава закріплює в Конституції дане суб'єктивне право держава вкладає в нього певний зміст, що виражається саме в його юридичному значенні. Право на життя не означає саме життя, цей суб'єктивний правочин, що має формально-атрибутивне оформлення. Тому варто відрізняти такі різні категорії, як право на життя та саме життя [22, с. 10-11].

Отже, право на життя, як і право на свободу, особисту недоторканість, $є$ самостійним суб'єктивним правом індивіда, яке проголошено як у Конституції України, так і у статтях Міжнародного пакту про громадянські і політичні права й інших 
міжнародно-правових актах [3; 24], і це дає можливість виділити це право як окремий самодостатній об'єкт кримінально-правової охорони. На нашу думку, необхідно говорити про виділення у Кримінальному кодексі України [27] окремого розділу «Злочини проти життя», який би забезпечував відповідний кримінальноправий захист життя людини як у біологічному, так i в соціальному розумінні [26, с. 35].

3 урахуванням конституційних положень про найвищу соціальну цінність життя людини в період розроблення нового Кримінального кодексу України неодноразово виголошувалися пропозиції про розміщення розділу про злочини проти особи на першому місці в Особливій частині Кримінального кодексу, як, наприклад, у Кримінальному кодексі Російської Федерації 1996 p. [28].

Український законодавець обрав інший шлях, передбачив у першому розділі Особливої частини Кримінального Кодексу відповідальність за злочини проти основ національної безпеки України [27]. Вказаний підхід аргументувався, зокрема, професором С.В. Дьяковим, який зауважив, що кожному зрозуміло, що скільки разів не став на перше місце особу, її права i свободи, реальна захищеність не буде забезпечена, якщо інститути державної влади слабкі та недієздатні $[29$, с. 11].

\section{2. Кримінально-правове законодавство закордонних країн про охорону життя та права на життя людини}

Цікавим із погляду нашого дослідження $\epsilon$ аналіз систем Особливої частини кримінального права країн романогерманської правової сім'ї.

Історично ці системи формувалися залежно від пріоритетів об’єктів, охоронюваних кримінальним законом. Так, для кримінального законодавства тих європейських країн, яке було ухвалено в XIX ст., система пріоритетів / охоронюваних кримінальним законом об'єктів виходить із переваги державних і суспільних інтересів над приватними інтересами. Наприклад, у Кримінальному кодексі Федеративної Республіки Німеччина (далі - ФРН), в основу якого покладено Уложення Германської імперії 1871 р., відповідальність за злочини проти життя встановлена лише у гл. 16 Кримінального кодексу ФРН, тобто після п'ятнадцяти глав Особливої частини, що регулюють відповідальність за інші злочини [30, с. 356]. Кримінальний 
Права людини в Україні та у зарубіжних країнах: традиції та новації

кодекс Голландії 1886 р. містить норми, що встановлюють відповідальність за посягання на життя людини, у розд. XIX «Злочини проти життя», починається ж Особлива частина Кримінального кодексу Голландії розд. I «Злочини проти безпеки держави» [31, с. 238-250, 384-386].

Така побудова Особливої частини кримінального законодавства цілком зрозуміла, тому що в час ухвалення зазначених кодексів у світі, зокрема й на європейському континенті, панувала саме така система цінностей, охоронюваних кримінальним законом (держава - суспільство особа). На підтвердження цього можна навести систему Особливої частини Кримінального кодексу (далі - КК) Японії 1907 р. (чинний у редакції 1995 р.) - азіатської держави, територіально віддаленої від Європи. У ньому зазначена система цінностей відбита, мабуть, найбільш ретельно (Особлива частина КК Японії розпочинається гл. 1 «Постанова щодо злочинів проти імператорської сім'ї», «Злочини, що полягають у вбивстві», передбачені гл. 26) [32, с. 66, 123].

Подібність системи зазначених пріоритетів у кримінальному законодавстві різних держав, розташованих навіть на різних континентах, пояснюється тим, що правова ідеологія законодавця характеризувалася тоталітарними рисами (для німецького й голландського законодавця це було XIX ст., і сучасна правова ідеологія цих держав давно зжила ознаки тоталітаризму), із чим і пов'язувалася перевага державних і суспільних інтересів над інтересами особи [33, с. 21].

Показова щодо цього Особлива частина Кримінального кодексу Франції 1810 р. (створений у період правління та за особистої участі Наполеона, Кодекс проіснував більше 180 років), яка включала два розділи: «Злочини і проступки проти публічних інтересів» та «Злочини і проступки проти приватних осіб» [34].

Однак Кримінальний кодекс Франції 1992 р. змінив зазначену систему, що було пов'язано з переглядом законодавцем ієрархії інтересів і цінностей, охоронюваних кримінальним законом, у напрямі встановлення пріоритету інтересів особи. Його Особлива частина відкривається книгою, присвяченою злочинам i проступкам проти особи (кн. II КК Франції 1992 р.) [33, с. 76-151]. Тоді як злочини проти держави винесено у кн. IV Кримінального кодексу Франції 1992 р. «Злочини і проступки проти нації, держави та громадського спокою» [35, с. 185-253]. 
Права людини в Україні та у зарубіжних країнах: традиції та новації

Така ж розстановка пріоритетів (особа - суспільство держава), охоронюваних кримінальним законом, властива й Особливій частині кримінального законодавства європейських країн, ухваленого в середині - наприкінці XX ст., як-от Кримінальний кодекс Швейцарії 1937 р. [36], Кримінальний кодекс Іспанії 1995 р. [37].

Можна зробити висновок, що система Особливої частини сучасного кримінального законодавства розвинених країн Європи має тенденцію до її побудови на принципах визнання пріоритету загальнолюдських цінностей, що насамперед виражається у кримінально-правовій охороні прав і свобод людини як основній ідеї кримінального права.

Позиція, відповідно до якої український законодавець (нехай і формально) віддає пріоритет державним інтересам, багато в чому носить відбиток стратегії попереднього історичного періоду. Плідним, на нашу думку, вбачається підхід зазначеної тріади цінностей - особа - суспільство - держава, коли охорона прав і свобод особи передбачається передусім, як формально, так і функціонально.

Наша пропозиція щодо розміщення розділу про злочини проти людини на першому місці в Особливій частині Кримінального кодексу України забезпечить реалізацію низки принципів, на яких вона побудована:

- по-перше, розділи в чинному Кримінальному кодексі України будуть розташовуватися відповідно до конституційних положень про пріоритетний захист інтересів особи;

- по-друге, розділи будуть розташовані в жорсткій, ієрархічно заданій послідовності, згідно зі ступенем важливості охоронюваних суспільних відносин, як це зазначено в ч. 1 ст. 1 КК України;

- по-третє, у розділах буде чітко простежуватися ідея законодавця вибудувати вертикаль норм у суворій залежності від ступеня значущості об'єктів кримінально-правової охорони [38].

Правової охорони потребує життя, що існує, тобто необхідність закріплення певної системи заходів захисту життя пов'язана з його початком. Питання, що стосуються визначення моментів початку і закінчення життя, отже, періоду, протягом якого існує необхідність охорони існуючого життя та захисту прав і законних інтересів фізичної особи, залишаються 
Права людини в Україні та у зарубіжних країнах: традиції та новації

актуальними як для медичних працівників, так i для правознавців різних галузей, зокрема й кримінальної.

Аналіз положень міжнародно-правових актів, як-от Декларація прав дитини ООН від 20 листопада 1959 р. [39], Конвенція про права дитини ООН від 20 листопада 1989 р. [40], Всесвітня декларація «Про забезпечення виживання, захисту та розвитку дітей» від 30 вересня 1990 р. [41], Міжнародний пакт про громадянські і політичні права від 16 грудня 1966 р. [3], дозволив зробити такі висновки: у текстах жодного із зазначених актів не встановлений прямий взаємозв'язок між моментом народження та правом на життя, інтереси та блага окремої людини мають пріоритет перед інтересами суспільства, дитиною $\epsilon$ людина до вісімнадцяти років (без вказівки нижньої межі), а невід'ємні права визнаються за кожною людиною незалежно від народження (аналіз текстів офіційними мовами дозволив відмовитися від пропонованого низкою дослідників пояснення, що термін «народження» повинен розглядатися як «походження»] [42, с. 43].

Декларація про медичні аборти, ухвалена в Осло 1 серпня 1970 р., основним принципом діяльності лікаря закріпила повагу до людського життя 3 моменту зачаття, що свідчить про визнання у плода людини такого блага, як життя [43].

Законодавством низки держав романо-германської правової сім'ї встановлений мораторій на дослідження ембріонів людини. Закони ФРН та Іспанії взагалі забороняють дослідження на ембріонах людини [44, с. 1117-1118]. У Франції, Данії дослідження на ембріонах людини обмежені в законодавчому порядку. Категорично заборонені дослідження на ембріонах людини з метою одержання біологічної зброї [45, с. 90].

У рекомендаціях Парламентської асамблеї Ради Європи (резолюція А2 327/88 від 16 березня 1969 р.) і в рішенні Комісії із прав людини (№ 6574/71) передбачено, що на ембріон і плід людини за будь-яких обставин поширюється вимога поваги людської гідності, отже, уже із цього моменту права людини мають основне значення [46, с. 56]. У преамбулі Декларації прав дитини говориться: «Дитина, через їі фізичну та розумову незрілість, потребує спеціальної охорони та турботи, включаючи належний правовий захист як до, так і після народження» [39]. Аналогічна вказівка міститься у преамбулі Конвенції ООН про права дитини [40]. 
В ухваленій 4 квітня 1997 р. Радою Європи Конвенції про права людини та біомедицину закріплена заборона на створення ембріонів людини в дослідницьких цілях, а також передбачено, що коли закон дозволяє проводити дослідження на ембріонах in vitro, він повинен передбачати належний захист ембріона [47].

Ще далі в цьому напрямі пішло цивільне право Франції, яке визнає існування життя ще до народження. «Стара римська максима infans conceptus знайшла своє відбиття в деяких статтях Цивільного кодексу Франції й базується на безперечних природничо-наукових даних: життя передує народженню» [46, с. 58]. Так, ст. 16 Цивільного кодексу Франції відбиває позицію «поваги людської істоти з початку її життя», яка розвинута в інших правових джерелах (Закон Франції «Про біоетику» від 29 березня 1994 р., Закон Франції «Про переривання вагітності» від 17 січня 1975 р., які встановили, що життя людської істоти має бути під захистом із моменту перших ознак його прояву) [46, с. 64].

Про тенденцію посилення інтересу до захисту людини до ії народження свідчить вимога Конвенції про захист прав і гідності людини у зв'язку із застосуванням досягнень біології й медицини про те, що коли «закон (конкретної держави) дозволяє проводити дослідження на ембріонах, він же повинен передбачати належний захист ембріона». У наведеному контексті також розглянута неоднозначна практика застосування положень міжнародно-правових актів [44]. Позиція Європейського суду, що використовує, серед іншого, формулювання «життя плода» й «обмеження, що накладаються на право на життя плода», свідчить про доцільність і своєчасності зміни підходів до статусу ненародженої дитини [42, с. 43].

Треба сказати, що вітчизняний законодавець займає компромісну позицію щодо визначення моменту, 3 якого починається життя людини. Так, відповідно до ст. 269 Цивільного кодексу (далі - ЦК) України, право на життя $\epsilon$ невід'ємним від носія, позбавленим економічного змісту, виникає в особи $з$ моменту народження чи іншого моменту, що прямо передбачено законом [48]. Відсильний характер має і ст. 6 Закону України «Про охорону дитинства» від 26 квітня 2001 р. № 2402-III [49], у якій зазначено, що «кожна дитина має право на життя 3 моменту визначення іï живонародженою та життєздатною за критеріями Всесвітньої організації охорони здоров'я» [49]. 
До цього в законодавстві України не було норми, у якій умовно визначався б початок життя людини. Однак для спеціалістів у сфері кримінального права такі критерії були вироблені в доктрині кримінального права [50, с. 32].

Загальноприйнятим положенням у кримінально-правовій науці було й залишається те, що життя людини розпочинається 3 моменту початку фізіологічних (зокрема, передчасних та штучно викликаних) пологів її матері. Водночас уважається, що не має значення для визначення цього моменту те, що дитина, яка народжується, ще не почала самостійного позаутробного життя і не відокремлена від черева матері [51, с. 6; 52, с. 348]. Практично це означає, що позбавлення життя дитини під час ії народження, тобто під час пологів їі матері, визнається вбивством. Протиправне ж знищення плода людини до цього моменту розцінюється не як вбивство, а як незаконне проведення аборту.

Вказана позиція стала панівною як у науковій, так і в навчальній літературі. Одним із перших такий погляд запропонував професор 0.0. Жижиленко, який першопочатковий момент людського життя визначав так: «До початку родів очевидним буде умертвіння плоду, а не вбивство, але як тільки роди почалися, особливо якщо частина новонародженого з'явилась назовні, можна говорити про народжену людину, убивство якої має бути караним» [53, с. 7]. Отже, початковим моментом людського життя професор 0.0. Жижиленко вважав початок фізіологічних родів.

На погляд учених, які дотримуються традиційного погляду на визначення моменту початку життя людини, вироблені в науці кримінального права критерії, згідно з якими життя людини розпочинається 3 моменту початку фізіологічних (зокрема, передчасних та штучно викликаних) пологів її матері, не суперечать положенням, які існують у медицині [50, с. 33]. У п. 1.2 Інструкції визначення критеріїв перинатального періоду, живонародженості та мертвонародженості зазначається, що живонародження - це вигнання або вилучення 3 організму матері плода, який після вигнання/вилучення (незалежно від тривалості вагітності, від того, чи перерізана пуповина і чи відшарувалась плацента) дихає або має будь-які інші ознаки життя, як-от серцебиття, пульсація пуповини, певні рухи скелетних м'язів [54]. Як видно, в Інструкції акцентується увага не на критеріях визначення, із якого моменту починається життя 
Права людини в Україні та у зарубіжних країнах: традиції та новації

людини, а на критеріях, які вказують на те, чи народилася людина живою.

Варто зазначити, що в сучасній кримінально-правовій літературі робляться спроби інакше визначити момент початку життя. Так, на думку професора В.О. Глушкова, життя плода людини після двадцяти восьми тижнів - додатковий об'єкт незаконного проведення аборту, тому його смерть унаслідок незаконної операції треба кваліфікувати як убивство [55, с. 21].

Також існує позиція, згідно з якою вбивством пропонується вважати позбавлення життя новонародженого на світ, який почав самостійну життєдіяльність [56, с. 9-13]. Дана думка, з тією чи іншою аргументацією, висловлювалась у науці кримінального права і раніше. Ще професор М.Д. Шаргородський початок життя людини пов'язував із початком дихання і моментом відділення пуповини [57, с. 59]. Такий підхід, на нашу думку, підміняє питання початку людського життя питанням живонародження плода. Як відзначав професор 0.0. Жижиленко, «оскільки людина ще жива, іiї життя охороняється незалежно від того, володіє людина життєздатністю чи ні. I щойно народжена дитина, що страждає такими вадами, що іï очікує неминуча смерть у майбутньому, кволий і старець, що помирає, охороняються однаково з людьми, що повні сил та здоров'я. Водночас не береться до уваги зовнішній вигляд людини та ступінь ії розумового розвитку» [53, с. 8$]$.

Деякий інтерес викликає думка, що «період внутрішньоутробного розвитку людини $\epsilon$ раннім періодом іiі біологічного життя. Перебуваючи в материнській утробі у стані ембріона, вона тілесно самостійна, тому що не $є$ частиною організму свого носія та здатна до саморозвитку: адже життєві процеси, що відбуваються в ній, виступають внутрішнім рушієм її розвитку. Тіло матері представляється тільки ідеальним середовищем розвитку ембріона, яке забезпечує його харчуванням, охороною. 3 народженням починається другий етап біологічного існування людини, а точніше, етап перебування іiі організму в соціальному середовищі. Це свідчить про помилковість наявної думки про те, що людське життя починається 3 його народження. Це варто скорегувати: соціальне життя людини починається 3 моменту іiі народження» [58, с. 13-14].

У юридичній науці намітилися стійкі тенденції підтримки саме цієї думки. Так, деякі вчені вважають, що «юридичне 
ставлення до статусу ембріонів повинно будуватися на основі визнання того факту, що ембріон - не частина організму матері, а початок нового життя. Це й повинно визначати підходи до створення відповідного правового регулювання, ставлення до абортів» [59, с. 12]. У цій частині доречно також навести думку авторитетного вченого, професора А.І. Ковлера: «Сучасне право рішуче визначає інший рубіж: життя людини починається із запліднення яйцеклітини» [60, с. 428].

Треба сказати, що умисне умертвіння дитини до пологів шляхом безпосереднього впливу на iї організм, 3 погляду чинного законодавства, не може визнаватися як убивство, а $\epsilon$ перериванням вагітності. I такий підхід, на думку багатьох вітчизняних і закордонних авторів, не можна визнати слушним [61, с. 299; 62, с. 53; 63, с. 75]. На думку професора 0.М. Попова, «законодавець зробив тільки півкроку у кримінально-правовій охороні життя, не пов'язавши відповідальність за такий злочин із кримінально-правовою охороною життя дитини, що перебуває в утробі матері» [64, с. 346].

Професор А.М. Орлеан зауважує, що життя людини може розпочатись не лише внаслідок фізіологічних пологів, а й унаслідок штучного вивільнення живого життєздатного плода 3 утроби матері шляхом, наприклад, кесаревого розтину. Дитина, яка була народжена таким способом, водночас із вивільненням 3 утроби матері отримує повноцінну кримінально-правову охорону [61, с. 304].

Слушною видається позиція професора Н.М. Ярмиш, яка звертає увагу на те, що «<...> умертвіння дитини навіть в утробі матері за умов, що пологи розпочались, а строк вагітності становить хоча б двадцять два тижні, - це вбивство» [65, с. 462]. Підтвердження наведеної тези вона бачить у диспозиції ст. 117 КК України, де йдеться про «умисне вбивство матір'ю своєї новонародженої дитини під час пологів або відразу після пологів <...». Професор Н.М. Ярмиш підкреслює, що цим визначенням охоплюється весь період пологів, а значить, початок пологів і $\epsilon$ початком життя людини $[65$, с. 463$]$. На розвиток розглянутої позиції існує думка, що оскільки двадцять другий тиждень вагітності не може в усіх без винятку випадках свідчити про життєздатність плода, варто враховувати й інші ознаки останньої (масу та розмір плода, відсутність несумісних із життям вад розвитку плода). Тому вчинене умисно посягання на 
Права людини в Україні та у зарубіжних країнах: традиції та новації

життя двадцяти двотижневого плода, який перебуває в утробі матері, після початку пологового процесу в разі його нежиттєздатності (за іншими критеріями) кваліфікуватимуться як замах на умисне вбивство [61, с. 306].

Отже, внутрішньоутробне позбавлення життя плода до початку пологового процесу залежно від сукупності наявних об'єктивних та суб'єктивних ознак може кваліфікуватись як незаконне проведення аборту (ст. 134 КК України) або тяжке тілесне ушкодження (ст. ст. 121, 123, 124, 128 КК України) [27]. Згідно з вітчизняним законодавством, повноцінну кримінальноправову охорону життя людина має або 3 моменту початку фізіологічних пологів (незважаючи на місце перебування плода: в утробі матері або зовні), або з моменту штучного вивільнення плода 3 утроби матері внаслідок кесаревого розтину. До цього моменту життя ембріона / плода людини може бути лише додатковим факультативним об'єктом у складах злочину, спрямованих на захист життя та здоров'я вагітної жінки $[61$, с. 306], або взагалі «випадає» із зони дії кримінального закону.

Ілюстрацією цього можуть слугувати приклади із судової практики, наведені у спеціальній літературі. Так, громадянка П., коли в неї на сьомому місяці вагітності настали передчасні пологи, народила дитину та втопила її у відрі з водою, за що була засуджена за дітовбивство («Умисне вбивство матір’ю своєї новонародженої дитини»).

В іншому разі суд відкинув обвинувачення громадянки С. у дітовбивстві, яка, будучи вагітною і бажаючи позбутися майбутньої дитини, приймала сильнодіючі медичні препарати, у результаті чого народила мертву семимісячну дитину. Поведінка громадянки С. негативно оцінюється 3 погляду моралі, але підстав притягнути ії до кримінальної відповідальності немає $[66$, c. $26-27]$.

Отже, розв'язання проблеми кримінально-правового закріплення моменту початку охорони життя варто шукати 3 урахуванням законодавчого досвіду країн романо-германської правової сім'ї. Так, німецький законодавець включив у розд. 16 «Злочинні діяння проти життя» КК ФРН [67] сім параграфів, які у спеціальній літературі називають «Злочини проти ненарожденого життя» [28, с. 372], а саме:

1) про відповідальність за переривання вагітності на строках більше дванадцяти тижнів без висновку лікаря, а також на 
строках вагітності більш двадцяти двох тижнів у разі відсутності надзвичайних показань (§ § 218, 218а КК ФРН);

2) про відповідальність лікарів і персоналу спеціальних клінік за порушення порядку проведення попередніх консультацій, видачі висновків і правил проведення аборту (§ § 218b, 218c, 219 КК ФРН);

3) про відповідальність за публічну агітацію за переривання вагітності, включаючи рекламу відповідних послуг «з корисливих цілей або у грубій негожій формі», а також за збут засобів і предметів, призначених для переривання вагітності (§ § 219a, 219b КК ФРН) [67, с. 127-131].

Однак німецький законодавець в особі Федерального Конституційного суду Німеччини у своїй судовій практиці дотепер залишає відкритим питання про те, з якого періоду життя починається захист конституційних прав людини. Федеральний Конституційний суд схиляється до того, що «людське життя починається $з$ моменту злиття яйцеклітини та сперматозоїда» [68, с. 127].

Стаття 3 пом'якшуючими обставинами для матері новонародженої дитини, подібна до ст. 117 КК України, у законодавстві Німеччини відсутня: працює загальне правило, відповідно до якого життя кожного повинно захищатися однаково. Якщо ж породілля перебуває в афективному стані, не цілком усвідомлює свої дії, то застосовуються відповідні норми про обмежену осудність вбивці, а суд заздалегідь не орієнтується на послаблення відповідальності за формальними ознаками [68, с. 16].

Необхідно відзначити, що у кримінальному законодавстві багатьох країн романо-германської правової сім'ї у злочинах, що посягають на життя та здоров'я вагітної жінки, об'єктом кримінально-правової охорони, крім життя та здоров'я самої жінки, виступає також і життя дитини, що не змогла з'явитися на світ через аборт, незалежно від строку вагітності. Така позиція стає очевидною, коли суб'єктом злочину називається не тільки особа, що робить аборт вагітній жінці за їі волею (а іноді й всупереч), але й сама жінка, що викликає в себе переривання вагітності (викидень) різними діями (способами). Водночас відповідальність вагітної жінки наступає і тоді, коли вона допускає переривання своєї вагітності за допомогою інших осіб. Така відповідальність передбачена, зокрема, кримінальними кодексами: Австрії (п. 3 §6) [69, с. 145], Аргентини (ст. 88) 
[70, с. 85], Бельгії (ст. 351) [71, с. 129], Іспанії (ч. 2 ст. 145) [37, с. 79], Сан-Марино (ст. ст. 153, 154) [72, с. 121-122], Швейцарії (ст. 118) [36, с. 162], Японії (ст. 212) [32, с. 128].

Також у закордонному кримінальному законодавстві криміналізовано здійснення аборту без згоди жінки. Така відповідальність встановлюється у Кримінальному кодексі Австрії (абз. 1 § 98 «Переривання вагітності без згоди вагітної»): «Хто перериває вагітність без згоди вагітної жінки, карається позбавленням волі на строк до 3 років, якщо діяння спричинило смерть вагітної жінки, - то позбавленням волі на строк від шести місяців до п'яти років» [69, с. 147]. У ст. 85 Кримінального кодексу Аргентини зазначено: «Той, хто зробив аборт, карається позбавленням волі на строк від 3 до 5 років каторжних робіт або тюремного ув'язнення, якщо діяв, не одержавши згоди жінки» $[70$, с. 84]. У ч. 5 ст. 126 Кримінального кодексу Болгарії передбачено: «Якщо вмертвіння плода здійснене без згоди вагітної, покарання - позбавлення волі від 3 до 8 років». У п. 3 ст. 296 Кримінального кодексу Голландії встановлено: «Якщо аборт був здійснений без згоди жінки, повинні бути призначені строк тюремного ув'язнення не більш 12 років або штраф п'ятої категорії» [31, с. 387].

Аналогічні положення закріплені у кримінальних кодексах Бельгії (ст. 348) [71, с. 127], Естонії (ст. 125) [73, с. 1140], Іспанії (ст. 144) [37, с. 49], Франції (ст. 223-10) [35, с. 217], Сан-Марино (ст. 153) [72, с. 121], Швейцарії (ч. 2 ст. 119) [36, с. 162], Японії (ст. ст. 215,216$)[32$, с. 130].

У деяких державах передбачена кримінальна відповідальність і за примушування жінки до здійснення аборту. Зокрема:

- ст. 136 Кримінального кодексу Латвії встановлено, що «примус вагітної до проведення аборту, якщо внаслідок цього аборт здійснений, карається позбавленням волі на строк до двох років або арештом, або примусовими роботами, або грошовим штрафом до сорока мінімальних місячних заробітних плат» [77, c. 157-158];

- у ст. 143 Кримінального кодексу Литовської республіки закріплено: «Той, хто, застосувавши фізичне або психічне насильство, примусив жінку до незаконного проведення аборту, карається публічними роботами або обмеженням волі, або арештом, або позбавленням волі на строк до двох років» [78, c. 251-252]; 
- $§ 1$ ст. 153 Кримінального кодексу Польщі передбачає: «Хто, застосовуючи насильство до вагітної жінки або іншим способом без іï згоди, перериває вагітність або шляхом насильства, протизаконної погрози, або шляхом обману доводить вагітну жінку до переривання вагітності, підлягає покаранню позбавленням волі на строк від шести місяців до восьми років» [79, с. 63];

- ст. 115 Кримінального кодексу Узбекистану встановлюється: «Примушування жінки до здійснення штучного переривання вагітності, якщо аборт був здійснений, карається штрафом до п'ятдесяти мінімальних розмірів заробітної плати або виправними роботами до двох років, або арештом до шести місяців» [80, с. 68].

Криміналізовано також порушення протипоказань до проведення аборту, зокрема, за кримінальним законодавством Узбекистану (ст. 114) [80, c. 67-68], Молдови (п. “d” ч. 1 ст. 159) [81, с. 327-328], Литви (ст. 142) [78, с. 250-251].

Ще одним злочином, передбаченим кримінальним законодавством різних країн романо-германської правової сім'ї, $\epsilon$ переривання вагітності 3 порушенням строків, за яких припустима така операція за законом. Так, зазначене положення міститься у Кримінальному кодексі Естонії (ч. 2 ст. 126) [73, с. 1140], Франції (п. 1 ст. 223-11) [35, с. 217].

Кримінальна відповідальність за замах на здійснення операції штучного переривання вагітності передбачається кримінальними кодексами Франції (ст. 223-11) [35, с. 218], Японії (ст. 215) [32, с. 130] тощо.

Під впливом законодавчої практики держав континентальної Європи в багатьох країнах аборт, проведений на пізніх строках вагітності, від дванадцяти до двадцяти двох тижнів, починають розглядати як убивство, незалежно від згоди та ролі в цьому самої вагітної жінки, за відсутності такої єдиної надзвичайної обставини, як необхідність порятунку життя самої жінки. Так, у 2004 p. у США ухвалений федеральний «Акт про захист ненароджених жертв насильства», у якому плід визнається людською істотою та має такі ж права, як і немовля.

Справжньою новелою для кримінального законодавства країн романо-германської правової сім'ї $\epsilon$ виділення у гл. 9 «Винні діяння проти особи» Кримінального (Пенітенціарного) кодексу Естонії окремого розд. 5 «Незаконне поводження з людським ембріоном» 
Права людини в Україні та у зарубіжних країнах: традиції та новації

[73, с. 1141], який містить чотири склади злочинів, які так чи інакше пов'язані зі злочинним впливом на ембріон людини (злочини, пов'язані 3 незаконним штучним перериванням вагітності містяться в розд. 4 цієї ж глави Кримінального (Пенітенціарного) кодексу Естонії [73, с. 1140-1141]).

Треба зазначити, що більшість статей цього розділу $\epsilon$ неоднозначними для сприйняття i, мабуть, потребують додаткового тлумачення 3 боку естонського законодавця. Зокрема, ст. 129 Кримінального (Пенітенціарного) кодексу Естонії «Завдання шкоди людському ембріону» визначає таке діяння, як завдання шкоди людському ембріону, що перебуває в матці, шляхом ушкодження, уведення якої-небудь речовини або іншими діями, якщо це спричинило переривання вагітності або загибель людського ембріона, злочином, що карається грошовим стягненням або тюремним ув'язненням на строк до п'яти років» $[73$, с. 1141]. Однак зі змісту цієї статті виходить, що будь-яке штучне переривання вагітності, здійснене, серед іншого, і в законному порядку, є діянням злочинним, хоча аборт (у разі дотримання певних правил) в Естонії не заборонений, про що свідчить наявність розд. 4 гл. 2 Кримінального (Пенітенціарного) кодексу Естонії.

Ст. 130 Кримінального (Пенітенціарного) кодексу Естонії «Заборонені дії 3 ембріоном» передбачає кримінальну відповідальність за клонування людини, а також за створення гібридної або химерної людини, що карається грошовим стягненням або тюремним ув'язненням на строк до трьох років [73, с. 1141].

Однак натепер вченими-генетиками зроблений висновок про неможливість одержання життєздатних стовбурних кліток від химерних (гібридних) ембріонів [82], отже, зазначена кримінально-правова норма натепер не має сенсу, до того ж міжнародної нормативної бази щодо цих створінь не існує, окрім, мабуть, положень загального характеру. Зокрема, у Рекомендації Ради Європи № 1046 від 24 вересня 1986 р. щодо використання ембріонів та плодів людини для цілей діагностики, терапії, наукових досліджень, промислового використання та торгівлі [83], у п. «Г» ст. 13 рекомендується звернутися із закликом до урядів держав-учасників заборонити все, що можна розглядати як небажане використання ембріона або плода, зокрема: 
- імплантацію людського ембріона в матку іншої тварини або навпаки;

- злиття гамет людини з гаметами іншої тварини;

- створення ембріона зі сперми різних людей;

- з'єднання ембріонів або будь-яку іншу дію, яка може призвести до появи химер [83].

Цілком доцільною видається норма, передбачена ст. 131 Кримінального (Пенітенціарного) кодексу Естонії «Неналежне поводження 3 людським ембріоном», у якій злочинним визначається екстракорпоральне створення людського ембріона, здійснене без мети перенесення ембріона в порожнину матки або поза установою, що має на те законне право, або особою, яка не має на те законного права, або екстракорпоральне зберігання людського ембріона в незамороженому виді понад встановленого законом строку, або здійснення угоди щодо людського ембріона у приватному порядку, що карається грошовим стягненням [73, с. 1141].

Законодавством України встановлені умови та порядок застосування штучного запліднення й імплантації ембріона (ембріонів) [74; 76; 86], однак жодний із вітчизняних нормативних актів, що стосуються цього питання, не містить інформації про конкретну відповідальність винних осіб за порушення зазначених умов та порядку.

Останньою в розд. 5 гл. 2 Кримінального (Пенітенціарного) кодексу Естонії стала ст. 132 «Незаконне сурогатне материнство», під яким розуміється перенесення чужої яйцеклітини або створеного 3 неї людського ембріона жінці, щодо якої відомо, що вона має намір після пологів відмовитися від розвиненої з ембріона дитини, що карається грошовим стягненням» $[73$, с. 1141].

Однак для України ця норма не є актуальною, оскільки, на відміну від Естонії, сурогатне (замінне) материнство в Україні дозволено, отже, законодавчо визначені умови та порядок застосування методу сурогатного материнства [74; 72].

Проведений аналіз законодавства країн романо-германської правової сім'ї дає можливість стверджувати, що вітчизняним законодавцем плід, що перебуває в утробі матері, незалежно від строку його розвитку розглядається як фізіологічна частина її організму, якою вона має право розпоряджатися за своїм розсудом. Це означає, що законодавець ставиться до ембріона як 
Права людини в Україні та у зарубіжних країнах: традиції та новації

до системи кліток, тканин і органів, що становлять частину жіночого організму, тобто, насамперед, як до якогось предмета (звідси випливає, що його можна продавати, знищувати тощо) $[75 ; 76]$. Якби законодавець ставився до ембріона як до суб’єкта правовідносин, визнавав його особливою, відособленою, самостійною частиною людини, що потребує захисту, то були б заборонені будь-які маніпуляції з ембріонами.

Але через те, що ненароджена дитина залежно від стадії розвитку являє собою або згусток людських тканин (ранній період ембріогенезу), або відособлену істоту, здатну жити поза організмом матері (починаючи із двадцять другого тижня), «зрівняти» їx y соціальному розумінні було б неправильно [84]. Тому розмежувальним строком (що розмежовує вбивство та незаконне проведення аборту), на нашу думку, може бути лише двадцять другий тиждень вагітності, тому що саме із цього моменту в акушерстві та гінекології аборт змінюється передчасними родами, викидень - життєздатним плодом, саме із цього моменту заборонене штучне переривання вагітності за соціальними показниками [85]. Уже починаючи із цього часу, за розвитком усіх органів і систем, плід здатний існувати поза утробою матері, і він повинен мати право на охорону його життя. На нашу думку, під час вирішення питання про початок людського життя необхідно виходити лише з медичних аргументів і висновків, які також свідчать на користь висловленої позиції.

Причиною таких змін стали досягнення в області сучасної медицини, які роблять можливим виживання плода на цій стадії розвитку. Можна припустити, що критерій життєздатності не $\epsilon$ стабільним. Отже, зміни в законодавстві щодо охорони здоров'я у даному питанні будуть вирішальними щодо тлумачення ознаки «життєздатності» [84].

Юридичне визначення моменту народження дозволило б возз'єднати основи кримінально-правової охорони життя людини та виникнення права на життя, що в сукупності 3 істотним за останнє десятиліття скороченням соціальних показань для штучного переривання вагітності можна розглядати як позитивний крок законодавця у справі розширення інституту правової охорони права людини на життя. 


\section{Висновки}

Отже, підбиваючи підсумок аналізу наявних позицій щодо життя людини та права на життя, уважаємо, що життя людини варто розглядати як природне поєднання іï біофізіологічного існування із соціальним функціонуванням її особистості. У такому сенсі життя людини не $\epsilon$ предметом правового регулювання, воно може виступати лише об'єктом правового захисту, зокрема і кримінально-правовими засобами.

Що ж до права на життя, то воно не означає саме життя, а $є$ певною правовою формою, суб'єктивним правочином із формально-атрибутивними ознаками, які закріплені в Конституції України та міжнародно-правових актах.

Варто констатувати, що життя людини в Україні ще не одержало належної кримінально-правової охорони. На нашу думку, кримінальне законодавство України в цій частині потребує відповідного реформування. У Кримінальному кодексі України необхідно передбачити, що посягання на життя дитини за строків вагітності понад двадцять два тижні незалежно від його місця знаходження (усередині або поза тілом матері) $\epsilon$ вбивством. До незаконного аборту треба відносити тільки випадки переривання вагітності за строку не більше двадцяти двох тижнів [38].

\section{Список використаних джерел:}

1. Конституція (Основний закон) Української Радянської Соціалістичної Республіки : Закон Української РСР від 20 квітня 1978 p. № 888-IX. URL: https://zakon.rada.gov.ua/laws/show/88809 (дата звернення: 30.03.2021).

2. Загальна декларація прав людини : Декларація Організації Об'єднаних Націй від 10 грудня 1948 р. Офіційний вісник України. 2008. № 93. Ст. 3103.

3. Міжнародний пакт про громадянські і політичні права Організації Об’єднаних Націй від 16 грудня 1966 p. URL: http://zakon0.rada.gov.ua/laws/show/995_043 (дата звернення: 30.03.2021).

4. Конвенція про захист прав людини і основоположних свобод Ради Європи від 4 листопада 1950 р. Дата ратифікації Україною: 17 липня 1997 р.. Дата набрання чинності для України: 11 вересня 1997 p. URL: http://zakon2.rada.gov.ua/laws/ show/995_004 (дата звернення: 30.03.2021). 
Права людини в Україні та у зарубіжних країнах: традиції та новації

5. Конвенція Співдружності Незалежних Держав про права та основні свободи людини від 26 травня 1995 p. URL: http://zakon4.rada.gov.ua/laws/show/997_070 (дата звернення: 30.03.2021).

6. Бабаджанов И.Х. Жизнь человека как социальная ценность и право на жизнь. Мир политики и социологии. 2012. № 2. C. 25-34.

7. Конституция Республики Болгарии. Конституции государств (стран) мира: Интернет-библиотека конститущий Романа Пашкова. URL: http://worldconstitutions.ru/archives/120 (дата звернення: 30.03.2021).

8. Основной закон Федеративной Республики Германия. Конституции государств (стран) мира : Интернет-библиотека конституций Романа Пашкова.

URL: http://worldconstitutions.ru/archives/155 (дата звернення: 30.03.2021).

9. Конституция Республики Албания. Конституции государств (стран) мира : Интернет-библиотека конституций Романа Пашкова. URL: http://worldconstitutions.ru/archives/104 (дата звернення: 30.03.2021).

10. Конституция Португальской Республики. Конституции государств (стран) мира : Интернет-библиотека конституций Романа Пашкова. URL: http://worldconstitutions.ru/archives/141 (дата звернення: 30.03.2021).

11. Конституция Республики Хорватия. Конституции государств (стран) мира : Интернет-библиотека конститущий Романа Пашкова. URL: http://worldconstitutions.ru/archives/107 (дата звернення: 30.03.2021).

12. Конституция Республики Словении . Конституции государств (стран) мира : Интернет-библиотека конституций Романа Пашкова. URL: http://worldconstitutions.ru/archives/109 (дата звернення: 30.03.2021).

13. Конституция Словацкой Республики. Конституции государств (стран) мира: Интернет-библиотека конституций Романа Пашкова. URL: http://worldconstitutions.ru/archives/110 (дата звернення: 30.03.2021).

14. Конституция Чешской Республики. Конституции государств (стран) мира: Интернет-библиотека конституций Романа Пашкова. URL: http://worldconstitutions.ru/archives/106/2 (дата звернення: 30.03.2021). 
15. Конституция Испанского Королевства. Конституции государств (стран) мира: Интернет-библиотека конституций Романа Пашкова. URL: http://worldconstitutions.ru/archives/149 (дата звернення: 30.03.2021).

16. Декларація незалежності : Права Людини в Україні. Інформаційний портал Харківської правозахисної групи : вебсайт. URL: http://www.khpg.org/index.php?id=946555693 (дата звернення: 30.03.2021).

17. Новгородцев П.И., Покровский И.А. О праве на существование : Социально-философские этюды. Москва ; СанктПетербург : Издание т-ва М.О. Вольф, 1911. 48 с.

18. Денисов А.И. Общая система социалистической демократии. Москва : Юрид. лит., 1975. 248 с.

19. Зайцева А.М. Жизнь человека как объект конституционно-правового регулирования : дис. ... канд. Юрид. наук: 12.00.02. Москва, 2009. 237 с.

20. Кримінальне право України : Особлива частина : підручник / за заг. ред. Є.Л. Стрельцова. Харків : Одіссей, 2009. 496 c.

21. «Неотъемлемые права» Декларации независимости. 230 лет США. Вашингтон, 2010. 24 с.

22. Романовский Г.Б. Гносеология права на жизнь. СанктПетербург : Юридический центр «Пресс», 2003. 370 с.

23. Шкурная Е.В. Жизнь как объект права : дис. ... канд. юрид. наук: 12.00.01. Москва, 2010. 150 с.

24. Конституція України : Закон України від 28 червня 1996 p. № 254к/96-BP. URL: https://zakon.rada.gov.ua/laws/show/ 254\%D0\%BA/96-\%D0\%B2\%D1\%80 (дата звернення: 30.03.2021).

25. Алексеев Н. Н. Основы философии права. СанктПетербург : Юридический ин-т, 1998. 256 с.

26. Стрельцов Є.Л. Реформа кримінального законодавства: осінні роздуми. Видавничий дім «Гельветика», 2019. 100 с.

27. Кримінальний кодекс України : Закон України від 5 квітня 2001 р. № 2341-III. URL: http://zakon2.rada.gov.ua/laws/ show/2341-14 (дата звернення: 30.03.2021).

28. Уголовный кодекс Российской Федерации. Принят Государственной Думой РФ 24 мая 1996 г. Собрание законодательства Российской Федерации. 1996. № 25. Ст. 2954.

29. Дьяков С.В. Преступления против основ конституционного строя и безопасности государства : уголовно- 
Права людини в Україні та у зарубіжних країнах: традиції та новації

правовое и криминологическое исследование. Санкт-Петербург : Юрид. центр «Пресс», 2012. 267 с.

30. Жалинский А.Э. Современное немецкое уголовное право. Москва : ТК «Велби»; изд-во «Проспект», 2006. 560 с.

31. Уголовный кодекс Голландии / науч. ред.: Б.В. Волженкин ; пер. с англ. : И.В. Миронова. 2-е изд. Санкт-Петербург : Юрид. центр «Пресс», 2001.510 с.

32. Уголовный кодекс Японии. С изменениями и дополнениями на 1 января 2002 г. / науч. ред. : А.И. Коробеев ; пер. с японск. : В.Н. Еремин. Санкт-Петербург : Юрид. центр «Пресс», 2002. 226 c.

33. Наумов А.В. Российское уголовное право. Курс лекций : в 2-х т. Москва : Юрид. лит., 2004. Т. 2 : Особенная часть. 832 с.

34. Александрова А.С. Французский Уголовный кодекс 1810 г. Санкт-Петербург : Изд-во С.-Петербургского гос. ун-та, 2007. 46 с.

35. Кримінальний кодекс Французької Республіки / за ред. В.Л. Менчинського ; пер. укр. мов. К.І. Мазуренко. Київ : ОВК, 2017.348 c.

36. Уголовный кодекс Швейцарии / науч. ред., предисл., пер. с нем. А.В. Серебренниковой. 2-е изд. Санкт-Петербург : Юридический центр «Пресс», 2002. 348 с.

37. Кримінальний кодекс Королівства Іспанія / за ред. В.Л. Менчинського ; пер. укр. мов. О.В. Лішевської. Київ : ОВК, 2017. 284 c.

38. Сотула О.С. Кримінально-правова охорона життя людини в країнах романо-германської правової сім'ї: ретроспектива, компаративістика, моделювання : монографія. Харків, 2015. 429 с.

39. Декларація прав дитини : Резолюція Організації Об'єднаних націй від 20 листопада 1959 p. URL: http://zakon4.rada. gov.ua/laws/show/995_384 (дата звернення: 30.03.2021).

40. Конвенція про права дитини : Конвенція Організації Об'єднаних націй від 20 листопада 1989 р. Зібрання чинних міжнародних договорів України. 1990. № 1. Ст. 205.

41. Всесвітня декларація про забезпечення виживання, захисту та розвитку дітей Організації Об’єднаних Націй від 30 вересня 1990 p. URL: http://zakon0.rada.gov.ua/laws/ show/995_075 (дата звернення: 30.03.2021).

42. Бабаджанов И.Х. Государственная политика в области охраны права внутриутробного ребенка на жизнь : 
законодательство России, Республики Таджикистан и других стран. Мир политики и социологии. 2012. № 1. С. 40-53.

43. Декларація, прийнята в Осло, стосовно медичного аборту : Декларація Всесвітньої медичної асоціації від 1 серпня 1970 p. URL: http://zakon2.rada.gov.ua/laws/show/990_009 (дата звернення: 30.03.2021).

44. Dickson D. Europe Split on Embryo Research. Science. 1998. V. 242. № № 48-82. Р. 1117-1118.

45. Медицина и права человека : Нормы и правила международного права, этики, католической, протестанской, иудейской, мусульманской и буддийской религиозной морали / пер. с фр. Г.В. Гаровникова ; ред. В.Д. Карпович. Москва : ПрогрессИнтер, 1992. 214 c.

46. Сент-Роз Ж. Право и жизнь. Вестник Московского университета. Серия 11 «Право». 2003. № 6. С. 56-69.

47. Конвенція про захист прав і гідності людини щодо застосування біології та медицини : Конвенція про права людини та біомедицину : Конвенція Ради Європи від 4 квітня 1997 p. URL: http://zakon0.rada.gov.ua/laws/show/994_334 (дата звернення: 30.03.2021).

48. Цивільний кодекс України : Закон України від 16 січня 2003 р. № 435-IV. Відомості Верховної Ради України. 2003. № № 40-44. Ст. 356.

49. Про охорону дитинства : Закон України від 26 квітня 2001 p. № 2402-III. Відомості Верховної Ради Украӥни. 2001. № 30. Ст. 142.

50. Мамчур В.М. Кримінальна відповідальність за умисне вбивство особи чи її близького родича у зв'язку з виконанням цією особою службового або громадського обов'язку : дис. ... канд. юрид. наук: 12.00.08. Київ, 2002. 207 с.

51. Бажанов М.И., Сташис В.В. Личность - под охраной уголовного закона. Симферополь : Таврия, 1996. 236 с.

52. Науково-практичний коментар Кримінального кодексу України / А.М. Бойко та ін. ; за ред. М.І. Мельника, М.І. Хавронюка. 10-е вид., переробл. та доп. Київ : ВД «Дакор», 2018. 1360 с.

53. Жижиленко А.А. Преступления против личности. Москва : Юрлитиздат, 1927. 236 с.

54. Про затвердження Інструкції з визначення критеріїв перинатального періоду, живонародженості та мертвонародженості, Порядку реєстрації живонароджених i мертвонароджених : наказ Міністерства охорони здоров'я 
Права людини в Україні та у зарубіжних країнах: традиції та новації

України № 179 від 29 березня 2006 р. Офіційний вісник України. 2006. № 15. Ст. 1150.

55. Глушков В.А. Ответственность за преступления в области здравоохранения. Киев : Вища школа, 1987. 200 с.

56. Красиков А.Н. Уголовно-правовая охрана прав и свобод человека в России. Саратов : Полиграфист, 1996. 211 с.

57. Шаргородский М.Д. Преступления против жизни и здоровья. Москва : Юрид. изд-во Минюста СССР, 1947. 511 с.

58. Селихова О.Г. Конституционно-правовые проблемы осуществления права индивидов на свободу и личную неприкосновенность : автореф. дис. ... канд. юрид. наук: 12.00.02. Екатеринбург, 2002. 23 с.

59. Беседкина Н.И. Конституционно-правовая защита прав неродившегося ребенка в Российской Федерации : автореф. дис. ... канд. юрид. наук: 12.00.02. Москва, 2005. 23 с.

60. Ковлер А.И. Антропология права : учебник для вузов. Москва : Норма -Инфра-М, 2002. 480 с.

61. Орлеан А.М. Початок кримінально-правової охорони життя людини. Вісник Академії правових наук України : збірник наукових праць. 2012. № 4 (71). С. 299-307.

62. Крылова Н. Е. Ответственность за незаконное производство аборта и необходимость уголовно-правовой защиты «будущей» жизни. Вестник Московского университета. 2002. № 6. С. 38-53.

63. Шарапов Р.Д. Начало уголовно-правовой охраны жизни человека: опыт юридического анализа. Уголовное право. 2005. № 1 . C. 75-77.

64. Попов А.Н. Убийства при отягчающих обстоятельствах. Санкт-Петербург : Юрид. центр «Пресс», 2003. 898 с.

65. Ярмыш Н.M. Содержание ст. 117 УК Украины как источник информации о начале жизни человека. Становлення держави та права в умовах глобалізації: теоретичний $i$ практичний аспект : матеріали II Міжнародної наукової конференції, 24 лютого 2012 р. Ніжин : Вид. ПП Лисенко М.М., 2012. С. 462-463.

66. Куринов Б.А. Борьба с преступными посягательствами на личность в СССР. Москва : Правда,1971. 112 с.

67. Уголовный кодекс Федеративной Республики Германии / науч. ред., вступ. ст. Д.А. Шестакова ; предисл. Г.-Г. Йешека ; пер. с нем. Н.С. Рачковой. Санкт-Петербург : Юридический центр «Пресс», 2003. 522 c. 
Права людини в Україні та у зарубіжних країнах: традиції та новації

68. Гиряева В.Н. 2004.02.038. Хеун В. Исследования эмбрионов и конституция: право эмбриона на жизнь и человеческое достоинство. Heun W. Embryonenforschung und verfassung: lebensrecht und menschenwuerde des embryos. Juristen zeitung. Tuebingen, 2002. № 11. S. 517-524. Социальные и гуманитарные науки. Отечественная и зарубежная литература. Серия 4 «Государство и право». Реферативный журнал. 2004. № 2. C. $126-129$.

69. Уголовный кодекс Австрии / науч. ред., вступ. ст. С.В. Милюкова ; предисл. Эрнста Ойгена Фабрици ; пер. с нем. Л.С. Вихровой. Санкт-Петербург : Юридический центр «Пресс», 2004. 550 с.

70. Уголовный кодекс Аргентины / науч. ред., вступ. ст. Ю.В. Голика ; пер. с исп. Л.Д. Ройзенгурта. Санкт-Петербург : Юридический центр «Пресс», 2003. 238 с.

71. Уголовный кодекс Бельгии / науч. ред., предисл. Н.И. Мацнева ; пер. с фр. Г.И. Мачковского. Санкт-Петербург : Юридический центр «Пресс», 2004. 559 с.

72. Уголовный кодекс Республики Сан-Марино / науч. ред., вступ. ст. С.В. Максимова ; пер. с ит. В.Г. Максимова. СанктПетербург : Юридический центр «Пресс», 2002. 251 с.

73. Уголовный (Пенитенциарный) кодекс Эстонской Республики. Правовые акты Эстонии. 2005. № 17. С. 1103-1220.

74. Сімейний кодекс України : Закон України від 10 січня 2002 p. № 2947-III. Відомості Верховної Ради України. 2002. № 21. Ст. 135.

75. Про затвердження Порядку застосування допоміжних репродуктивних технологій в Україні : наказ Міністерства охорони здоров'я від 9 вересня 2013 № 787. Офіційний вісник України. 2013. № 82. Ст. 3064.

76. Основи законодавства України про охорону здоров'я : Закон України від 19 листопада 1992 р. № 2801-XII. Відомості Верховної Ради України. 1993. № 4. Ст. 19.

77. Уголовный кодекс Латвийской Республики. Принят 8 июля 1998 г. Введен в действие с 1 апреля 1999 г. С изменениями и дополнениями на 1 августа 2001 г. / науч. ред. : А.И. Лукашов ; пер. Э.А. Саркисова. Санкт-Петербург : Юрид. центр «Пресс», 2001. 313 с.

78. Уголовный кодекс Литовской Республики / науч. ред. В. Павилониса ; предисл. Н.И. Манцева ; вступ. ст. В. Павилониса, 
Права людини в Україні та у зарубіжних країнах: традиції та новації

А. Абрамавичюса, А. Дракшене ; пер. с лит. В.П. Казанскене. СанктПетербург : Юрид. центр «Пресс», 2003. 468 с.

79. Кримінальний кодекс Республіки Польща / за ред. В.Л. Менчинського ; пер. укр. мов. В.С. Станіч. Київ : ОВК, 2017. $138 \mathrm{c}$.

80. Кримінальний кодекс Республіки Узбекистан / за ред. В.Л. Менчинського ; пер. укр. мов. О.В. Іванов. Київ : ОВК, 2019. 194 c.

81. Кримінальний кодекс Республіки Білорусь, Кримінальний кодекс Республіки Молдова : збірник / за ред. В.Л. Менчинського ; пер. укр. мов. Т.В. Руденко. Київ : ОВК, 2016. 462 c.

82. Стволовые клетки химерных эмбрионов не будут использовать в лечении людей. Московский городской Фонд ДНКисследований. URL: http://dnk-gf.ru/newsline/big.php?num=3 (дата звернення: 12.04.2021).

83. Рекомендація 1046 (1986) щодо використання ембріонів та плодів людини для цілей діагностики, терапії, наукових досліджень, промислового використання та торгівлі : Рекомендації Ради Європи від 24 вересня 1986 p. URL: http://zakon0.rada.gov.ua/laws/show/994_070 (дата звернення: 12.04.2021).

84. Гергердт К.И. К вопросу о начале уголовно-правовой охраны человеческой жизни. Научная библиотека Сибирского федерального университета. URL: http://library.krasu.ru/ft/ft/ b72/0227142/pdf/10/50a.pdf (дата звернення: 12.04.2021).

85. Про затвердження Порядку надання комплексної медичної допомоги вагітній жінці під час небажаної вагітності, форм первинної облікової документації та інструкцій щодо їх заповнення : наказ Міністерства охорони здоров'я від 24 травня 2013 № 423. URL: https://zakon.rada.gov.ua/laws/show/z1095-13 (дата звернення: 12.04.2021).

86. Про затвердження Порядку застосування допоміжних репродуктивних технологій в Україні : наказ Міністерства охорони здоров'я від 9 вересня 2013 № 787. URL: https://zakon.rada.gov.ua/laws/show/z1697-13 (дата звернення: 12.04.2021). 